九州大学学術情報リポジトリ

Kyushu University Institutional Repository

Immunohistochemical Evidence that P-

Glycoprotein in Non-Small Cell Lung Cancers is Associated with Shorter Survival

横山，秀樹

https://doi.org/10.11501/3175070

出版情報：九州大学，2000，博士（医学），論文博士 バージョン：

権利関係 : 


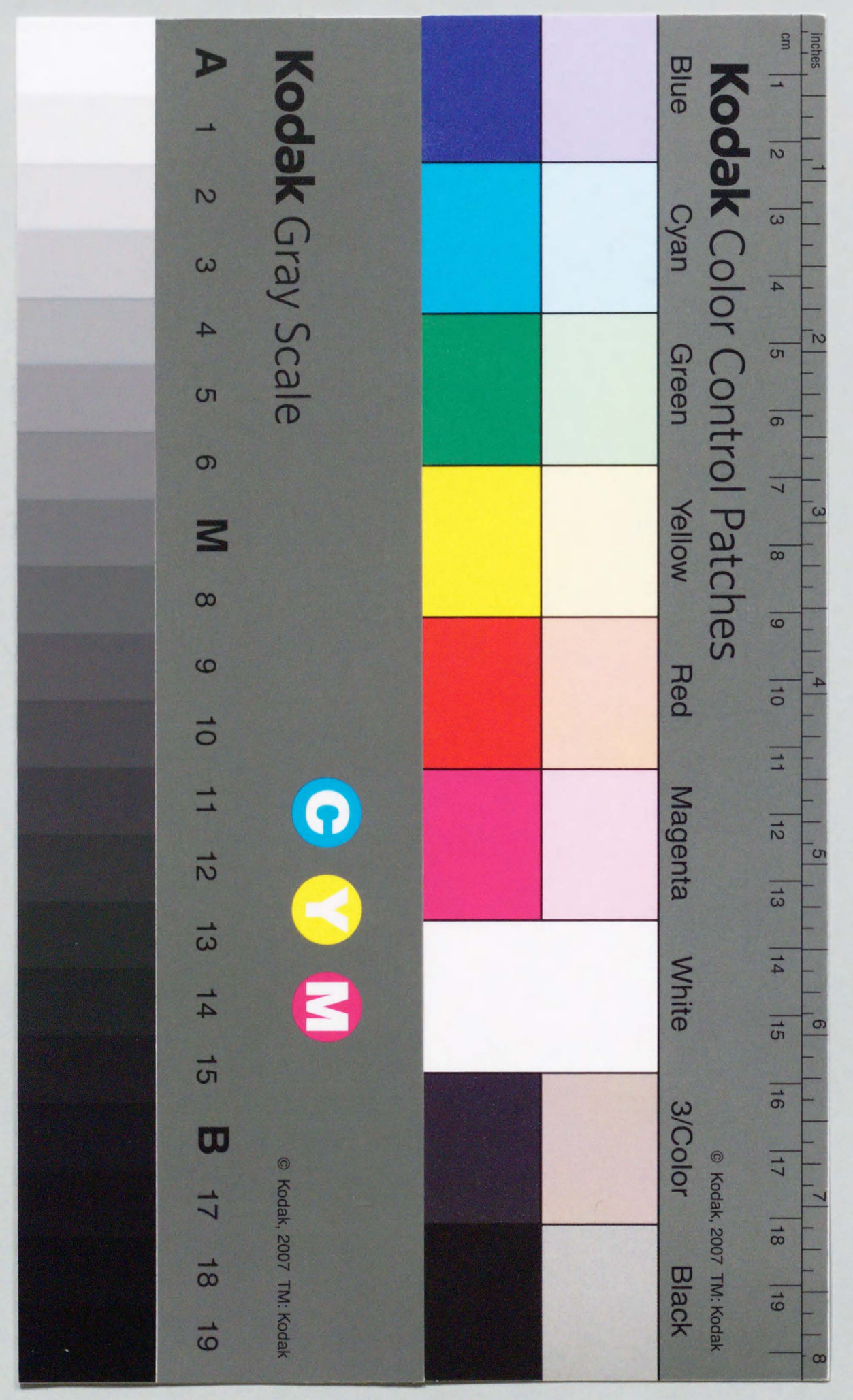




\section{Immunohistochemical Evidence that P-Glycoprotein in Non-Smal Cell Lung Cancers is Associated with Shorter Survival}

Hideki Yokoyama. Teruyosil Ishida. Kenu Sugio, Takasmi Inouf, and Keizo Sugimach

Department of Surgery II. Faculty of Medicine, Kvushu Unirersity, 3-1-1 Maidashi. Higashi-ku, Fukuoka \$12-8582. Jappan

Alstract: The expression of P-glycoprotein in 159 non-small a monoclonal antibody (MoAb C219). A total of $93(61) \%$ cancers were found to be positive for P-glycoprotein. The -year survival rales of patients with P-glycoprotein (P-gp + and those without P-glycoprotein (P-gp-) were $47.6 \%$ and

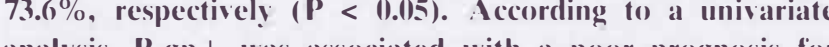
malys, P-gpt

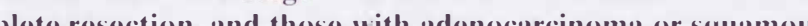

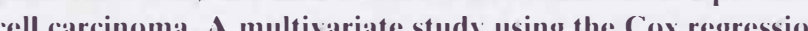
analssis indicated that the expression of P-glycoprotein is useful for predicting the prognosis. Among 24 patients who underwent complete resection and postoperative adjuvan chemotherapy, 18 were P-gp+ and the remaining 6 were Pp-. Of the 18 with P-gp+ cancer, 11 relapsed and 9 died Irom tumor-related causes, while the other 7 remain free from (umor recurrence; howerer, all with P-gp- cancer are aliv without recurrence. These ohservations suggest a bias toward a shorter survival for patients with P-gp+ cancer because $\mathbf{p}$ dycopsen

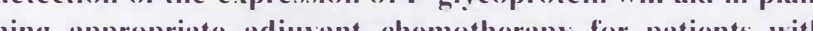
non-small cell lung cancer.

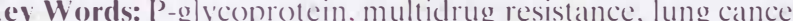
immunohistochemistry. postoperative chemotheraly

Introduction

Lung cancer is one of the leading causes of death from disease in Japan and its incidence is increasing rapidly.

Reprint requests to: H. Yokovama

This work was supported in part by a Grant-in-Aid for General scientific Rescearch (No. 0.3670659) from the Ministry

Received for publication on May 25. 1998: accepted on Ma
The length of survival strongly depends on the stage of the disease, such as TNM status and the curability of surgerv. ${ }^{2}$ However. recurrence, regional and distant. requently develops in patients who have undergone complete resection. ${ }^{3.4}$ Patients with stage I disease have 5 -year survival rates between $50 \%$ and $70 \%$. ${ }^{2.5} \mathrm{~A}$ more favorable prognosis can often be achieved if postoperative adjuvant chemotherapy is prescribed:" however. adjuvant chemotherapv has been found to be of little benefit for patients with non-small cell lung cancer?.x Tumor cells are often resistant to various drugs that are functionally and/or structurally different. One of the most widely studied types of drug resistance is the phenomenon of an overexpressed multidrug resistance gene (mdrl) product, a $170 \mathrm{kDa}$ membrane-spanning protein. usually referred to as P-glvcoprotein." A number of efforts have been made 10 determine the mechatnisms associated with mdrl or P-glycoprotein, and it has been revealed that P-glycoprotein functions as an energy-dependent efflux pump to decrease intracellular drue acemulation 11) This property has the petential of influencing the outcome of chemotherapy. because a significant number of anticancer drugs are substrates for transport by this protein To investigate its clinical significance, we immuno-
histochemically examined the expression of $P$ glycoprotein in resected non-small cell lung cancer

\section{Materials and Method}

\section{Patuients and Manerial:}

Materials were obtained from 159) patients who underwent surgery for non-small cell lung cancer in the Whire Furgery II. Faculty of Medicine. Kyushu were

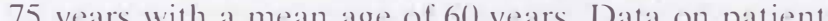


who died within the first postoperative month or who underwent exploratory thoracotomy were excluded from the analysis in the present study. None of the patients had received preoperative chemotherapy and or radiotherapy, but 24 had been given postoperative adjuvant chemotherapy.

For the assessment of the TNM classification for lung cancer. we followed the guidelines of the International Union Against Cancer. There were 77 patients with stage 1, 9 with stage H. th with stage IIIA. Is with stage IIIB. and II) With stage TV cancer. Fistology of the disease was determined according to the WHO classification. ${ }^{13}$ There were 92 patients with adenocarcinoma. 57 with squamous cell carcinoma. and 10 with large cell carcinoma. Complete resection of the tumor by lobectomy or pneumonectomy combined with hilar and mediastinal lymphadenectomy wals performed whenever feasible, as the standard surgical treatmem.

Immunohisuchemisery

The primary monoclonal antibody (MoAb (219) was oblamed from Centeor Diagnostics Aatrem. PA. USA). MoAb (219) is a murine monoclonal antibody subclass IgG2a. which binds to a highly conserved cytoplasmic epitope of P-glvcoprotein. Indirect staining wals done using the labeled avidin-biotin (LAB) method. If Immunohistochemical staining was conducted by emploving the following process. After 4 um-thick sections had been cut and fixed in cold acetone for $15 \mathrm{~min}$. they were incubated with primary monoclonal antibodv (MoAb (219) at a concentration of $15 \mathrm{\mu g} / \mathrm{ml}$ for $2 \mathrm{~h}$. The sections were then exposed to a biotinylated secondary antibody and avidin with horseradish peroxidase (Nichirei, Tokyo, Japan) for $30 \mathrm{~min}$ and 10 min, respectively. After this treatment, visualization of the perovidase was achleved by the diaminobenzidine method. Each section was stained with methyl green and examined under a transmission light microscope

Nonmmune mouse serum was emploved for the controls. Using MoAb C219. purified P-glycoprotein conjugates. and diluted antiserum (1:50), the specificity of MoAb C219 was tested by an absorption test. When the sections were incubated with purified P-glycoprotein conjugate, then with anti-p-glycoprotein serum, the staining result was negative.

\section{Counting Procedure}

For each section, we examined ten high-power fields at random, and in each field we checked the immunoreactivity of 100 tumor cells. The extent of anti-Pwhen tes than $25 \%$ the rivity was scored as negalive as positive when $2.5 \%$ or more of the tumor cells were stained.

Statistical Analysis

The BMDP statistical package program (BMDP. Los Angeles. (A. USA) for the HBM (Armonk, NY. USA) +381 maintrame computer was used for statistical analyses. ${ }^{\text {to }}$ The chi-squared test or Fisher's exact test was used to analyze the statistical significance of difference between the immunohistoreactivity for P-glycoprotein and the factors of sex. TNM stage. curability of the operation, histological type, and the degree of differendiation. Fisher's exact test was used when there were six or fewer items in a group. and survival rates were calculated by the Kaplan-Meier method. ${ }^{17}$ (Comparison among survival rates was made using the log-rank test. The BMDP P2L program was used for the multivariate adjustment of covariates, such as sex, age. Brinkman index. TNM status. stage, size of the tumor, histology. degree of differentiation. and curability of the oper tion, simultaneously by the Cox regression analysis 19 . all analyses, a critical level of significance of 0.05 w. chosen.

\section{Results}

Immunohistochemistry

Immunoreactivities for P-glycoprotein were in the co membrane and ckoplasm of the matignant cells (Fi IA.B). but the normal alveolar epithelium and strom were not stained. Of the 1.59 patients examined. the were $96(6) \%$ ) with a positive immunoreactivity for p- $^{-}$ glycoprotem and 6.3 (40\%) with a negative immunoreactivity. as shown in Table 1 . Dalta assessed included the lactors of se. metastasis status (M). stage, histology, and curability or the operation, according to the extent of anti-pglycoprotein immunoreactivity. There was no statistical significance in the incidence of anti-P-glycoprotein immunoreactivity in any of the factors. except for the histological type. In large cell carrcinomas. the incidence of positive immunoreactivity was less than that in adenociarcinomals or squamous cell carremomas $(P<0.0 .5)$

Prognestic Studie:

As shown Fig. 2, the 5-year overall survival rates of paticnts with olycoprotein (P-opt) and those witheil glycoprotein (P-op-) were $48 \%$ and $74 \%$ respectively glycoprotem (P-gp-) were $48 \%$ and $74 \%$. respectively clinicepathologect hactors of patients separated by the

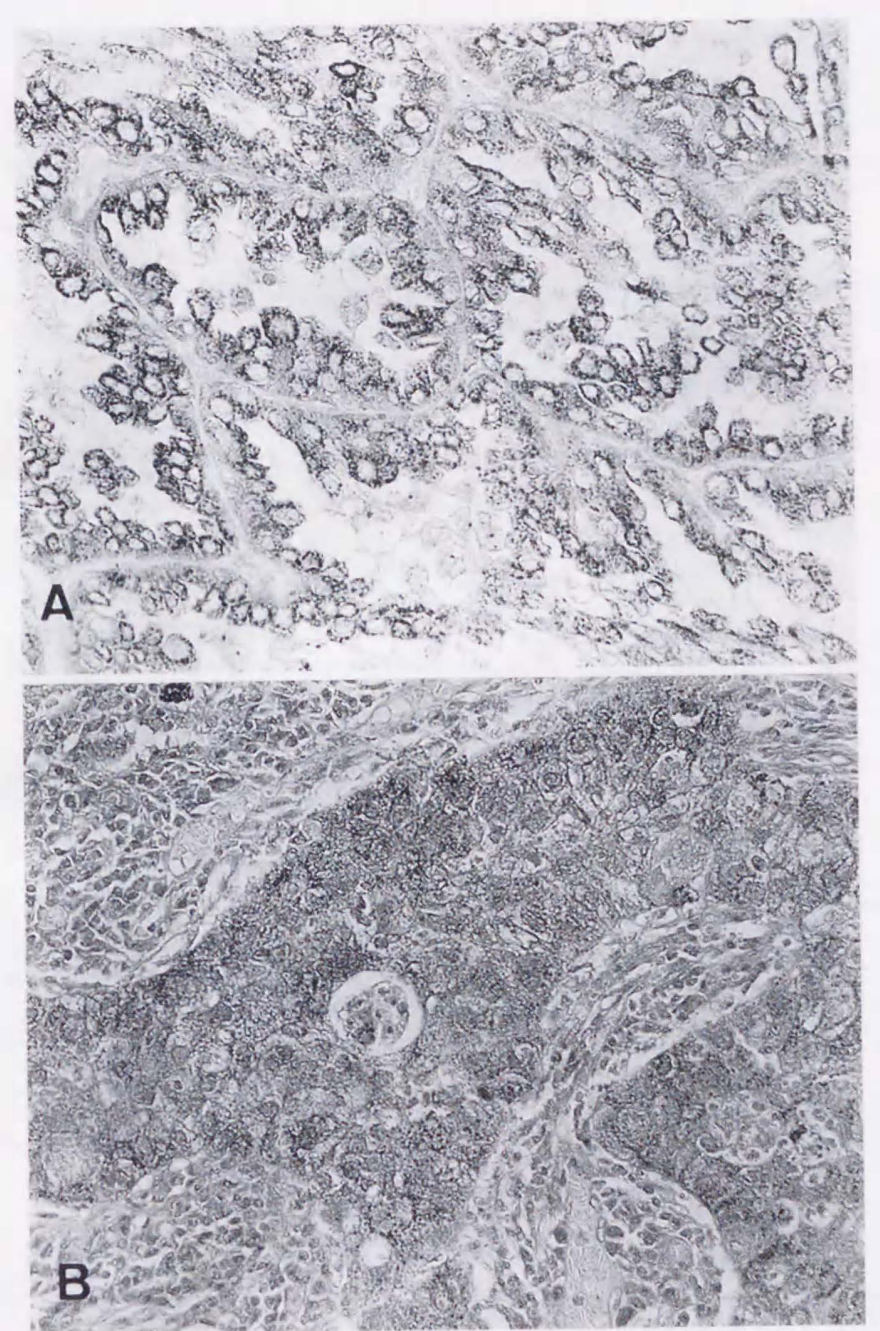

Fig. 1A.B. Immunohistochemistry of adenociarcmomia. show ing diffuse cytoplasmic and membrante staining for P$\times 5.50)$

anti-P-glycoprotein immunoreactivity for the various factors are given in Table 2. When lactors such as male sex adenocarcinoma. squamous cell carcinoma. and complete resection were assessed. statistically significant diflerences were found in the sarist rates of P-gp + patients and P-gp-patients. We also evaluated the pattern of immunoreactivity or P-glycoprotein. but there were no statistically signifieant difterences in the survival rates of patients with locally positive P-glycoprotein, those with diffusely positive P glycoprotem. and those without P-glycoprotem (dat not shown)

Table 3 summarizes the results of the Cox regression analysis of the dependence of survival upon the expression of P-glycoprotein and other covariates. The expression of P-glycoprotem was seen to have prognostic significance when all covariates were included in the Cox regression analysis.
Gable 1. Relationships among the immunoreactivities of patients with non-small cell lung cencer

\begin{tabular}{|c|c|c|c|}
\hline \multirow{2}{*}{ Variahles } & \multirow{2}{*}{$\begin{array}{l}\text { No. of } \\
\text { patients }\end{array}$} & \multicolumn{2}{|c|}{ P-glycoprotein } \\
\hline & & + & - \\
\hline \multicolumn{4}{|l|}{ Sex } \\
\hline $\begin{array}{l}\text { male } \\
\text { female }\end{array}$ & $\begin{array}{r}111 \\
48\end{array}$ & $\begin{array}{l}64 \\
32\end{array}$ & $\begin{array}{l}47 \\
16\end{array}$ \\
\hline \multicolumn{4}{|l|}{$\begin{array}{l}\text { lemale } \\
\text { Tumor } \\
1\end{array}$} \\
\hline $\begin{array}{l}1 \\
2\end{array}$ & 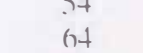 & $\begin{array}{l}30 \\
34\end{array}$ & 24 \\
\hline$\frac{2}{3}$ & is & i1) & 25 \\
\hline \multirow{2}{*}{\multicolumn{4}{|c|}{$\begin{array}{c}4 \\
\text { Nodes } \\
\text { (1) }\end{array}$}} \\
\hline & & & \\
\hline $\begin{array}{c}0 \\
1 \\
1\end{array}$ & 48 & $\begin{array}{c}56 \\
9\end{array}$ & \\
\hline $\begin{array}{l}1 \\
2\end{array}$ & 48 & 29) & $\frac{2}{19}$ \\
\hline$\overline{3}$ & 1 & 1 & () \\
\hline \multicolumn{4}{|l|}{ Metastasis } \\
\hline & 1.48 & 88 & $(x)$ \\
\hline & 10) & & \\
\hline $\begin{array}{c}\text { Stage } \\
1\end{array}$ & 77 & 45 & .32 \\
\hline 11 & 1) & 7 & 2 \\
\hline $111 \mathrm{~A}$ & 44 & 2.4 & 20) \\
\hline & 18 & $12 \frac{12}{7}$ & 6 \\
\hline \multirow{2}{*}{\multicolumn{4}{|c|}{$\begin{array}{l}\text { IV } \\
\text { Histolongy }\end{array}$}} \\
\hline & & & \\
\hline $\begin{array}{l}\text { adenociarcinoma } \\
\text { squamous cell carcinoma }\end{array}$ & 57 & 31 & 26 \\
\hline large cell carcinoma & 10 & 3 & $7=$ \\
\hline \multicolumn{4}{|l|}{ Degree of differentiation } \\
\hline well & 67 & 42 & 25 \\
\hline moderately & 63 & 37 & 26 \\
\hline & 28 & 16 & 12 \\
\hline $\begin{array}{l}\text { Curathility of operation } \\
\text { complete }\end{array}$ & 125 & 77 & 48 \\
\hline incomplete & 34 & 11) & 15 \\
\hline Total & 154) & 96 & 63 \\
\hline
\end{tabular}

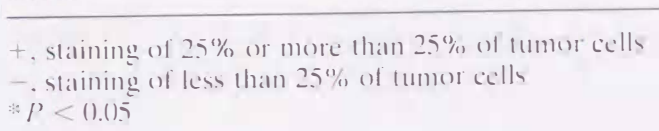

The postoperative courses of the 24 patients who underwent complete resection and postoperative adjuvan chemotherapy are shown in Fig. 3. These patients were treated with two or three cycles or PAP chemotherapy. comprised of pepleomycin $5 \mathrm{mg} / \mathrm{m}^{2}$. adriamycin $30 \mathrm{mg} / \mathrm{m}^{2}$. and cisplatin $50 \mathrm{mg} / \mathrm{m}^{2}$, or ( VPP chemotherapy. comprised of cyclophosphamide $400 \mathrm{mg} / \mathrm{m}^{2}$. vindesin $4 \mathrm{mg} / \mathrm{m}^{2}$, and cisplatin $50 \mathrm{mg} / \mathrm{m}^{2}$. Five of these patients were also treated with 3()-45 Gy radiotherapy. Among the 24 patients treated with chemotherapy. Is were $P$-gp + and the others were P-gp-. Of the 18 who were $\mathrm{P}$-gp,+ 11 developed a recurrence and 9 died from tumor-related causes. Conversely, none of the patients who were P-gp-developed recurrence and all were alive at the time of writing. 


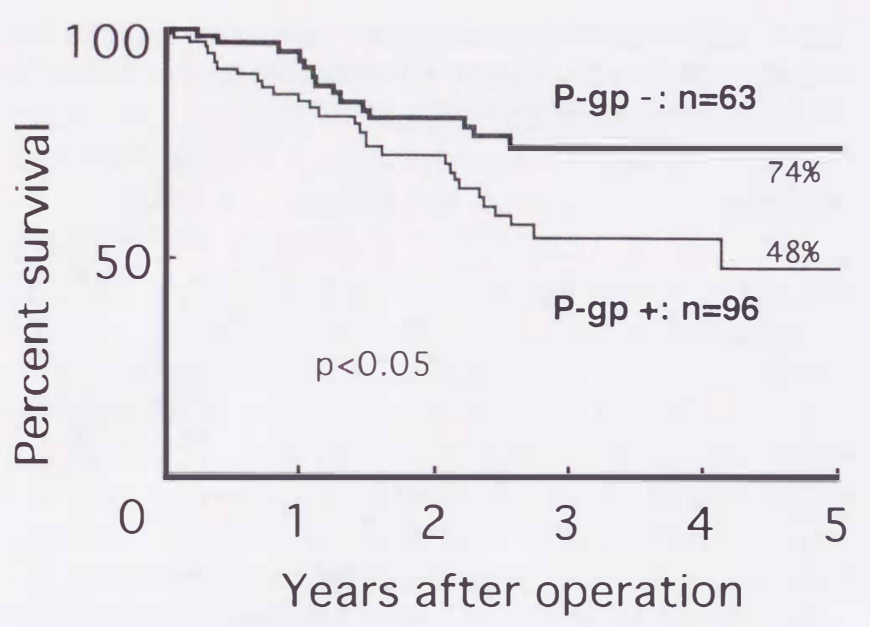

Fig. 2. Survival curves of patients with non-small cell lung activity for P-glycoprotein

Tallte 2. Survival rates according to various prognostic factors based on the detection of P-glycoprotein

\begin{tabular}{|c|c|c|c|c|c|c|c|}
\hline \multirow[b]{2}{*}{ Variables } & \multirow{2}{*}{$\begin{array}{l}\text { No. of } \\
\text { patients }\end{array}$} & \multicolumn{5}{|c|}{ Percent survival (years) } & \multirow[b]{2}{*}{$P$ Value } \\
\hline & & 1 & 2 & 3 & 4 & 5 & \\
\hline \multicolumn{8}{|l|}{ Sex } \\
\hline male & & & & & & & \multirow{2}{*}{ 0..0478: } \\
\hline $\begin{array}{l}P-g p+ \\
P-g p-\end{array}$ & 47 & 80 & 75 & 60 & $+\infty$ & 二 & \\
\hline \multicolumn{8}{|l|}{ female } \\
\hline P-gp+ & 32 & 92 & 87 & 66 & 52 & 52 & \multirow[t]{2}{*}{0.1394} \\
\hline \multirow{2}{*}{\multicolumn{8}{|c|}{$\begin{array}{c}\text { Tumor } \\
1\end{array}$}} \\
\hline & & & & & & & \\
\hline P-gp+ & 30) & 100 & 95 & 81 & 81 & 81 & \multirow[t]{2}{*}{0.2600} \\
\hline \multicolumn{7}{|l|}{$2-1$} & \\
\hline$P-g p+$ & 3) & 80 & 70) & 54 & 54 & 36 & \multirow{2}{*}{0.1308} \\
\hline${ }_{3}^{P-g p}-$ & 25 & 96 & 8.5 & 73 & 73 & 73 & \\
\hline$P-g p+$ & 10 & 90 & 51 & 13 & 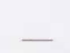 & - & \multirow{2}{*}{0.3720} \\
\hline \multirow{2}{*}{\multicolumn{8}{|c|}{4}} \\
\hline & & & & & & & \\
\hline$P=-g p-$ & 6 & 67 & 50 & 33 & - & - & \multirow{2}{*}{$0.76+1$} \\
\hline \multicolumn{7}{|l|}{$\begin{array}{c}\text { Nodes } \\
0 \\
0\end{array}$} & \\
\hline P-gp+ & 56 & 94 & 77 & 67 & 67 & 67 & \multirow[t]{2}{*}{0.0737} \\
\hline$P-g p-$ & +2 & 94 & 89 & 85 & 8.5 & 85 & \\
\hline & & \\
\hline$P-g P^{-}$ & 2 & 100 & 100 & 1010 & 100 & 100 & \multirow{2}{*}{$0.36+2$} \\
\hline & \\
\hline$P-g p-$ & 19 & 89 & 62 & 48 & 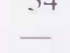 & - & \multirow{2}{*}{0.4095} \\
\hline \multicolumn{7}{|l|}{$\begin{array}{c}\text { Metastisis } \\
0\end{array}$} & \\
\hline$P-g p+$ & 88 & 88 & 75 & 61 & 61 & & \multirow{2}{*}{$0.11+1$} \\
\hline$P$-gp - & 60) & 93 & 81 & 74 & 74 & 74 & \\
\hline P-gp+ + & 6 & 71 & 71 & () & () & () & $(0.3) .34$ \\
\hline P-gp- - & 3 & 100 & 67 & 67 & & - & \\
\hline
\end{tabular}

\section{Discussion}

H. Yokoyama et al. P. Gilycoprotein and Lung Cancer

P-Glycoprotein is a 170 kDa transmembrane protei associated with the chemoresistance of cancer cells. which is encoded by the multidrug resistance gene (modri)." This protem is an encrgy-dependent efflux pump capable or decreasing the intracellular concentrafion of a broad range of cytotoxic compounds. ${ }^{20.23} \mathrm{~W}$ obtained immunohistochemical evidence that the expression of P-glveoprotein was associated wilh shorter whr whor

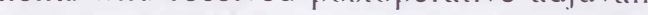
hes

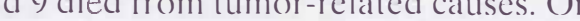
the other hand, all with P-gp-cancer are alive withou recurrence. Although the number of patients in this

\begin{tabular}{|c|c|c|c|c|c|c|c|}
\hline \multirow[b]{2}{*}{ Variables } & \multirow{2}{*}{$\begin{array}{l}\text { No. of } \\
\text { patients }\end{array}$} & \multicolumn{5}{|c|}{ Percent survival (years) } & \multirow[b]{2}{*}{$P$ Valuc } \\
\hline & & 1 & 2 & 3 & 4 & 5 & \\
\hline \multicolumn{8}{|l|}{ Stage } \\
\hline P-gpt & 4.5 & 95 & 88 & 78 & 78 & 78 & \multirow[t]{2}{*}{$0.0138 *$} \\
\hline$P-g p^{-}$ & 32 & 100 & 100 & 100 & 100 & 100 & \\
\hline \multicolumn{8}{|l|}{ II } \\
\hline$P-g p^{-1}$ & 2 & 100 & 100 & 100 & 100 & 100 & 0.31 .37 \\
\hline \multicolumn{8}{|l|}{$111 A^{-11}$} \\
\hline $\begin{array}{l}\text { P-gp+ } \\
\text { P-gp- }\end{array}$ & 20 & $\begin{array}{l}81 \\
9(0)\end{array}-20$ & 6.3 & 51 & 51 & - & 0.3314 \\
\hline \multicolumn{8}{|l|}{ 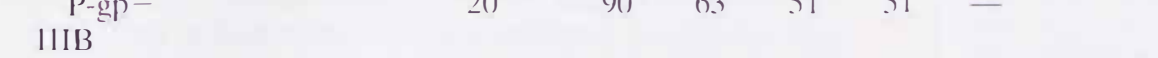 } \\
\hline $\begin{array}{l}\text { P-gp+ } \\
\text { P-gp- }\end{array}$ & $\frac{12}{6}$ & $\begin{array}{l}72 \\
67\end{array}$ & $\begin{array}{l}6(1) \\
50\end{array}$ & $\begin{array}{l}60 \\
33\end{array}$ & 60) & 6(1) & 0.5714 \\
\hline \multicolumn{8}{|l|}{$I^{P \text {-gp }}$} \\
\hline $\begin{array}{l}P-g p+ \\
P-g p-\end{array}$ & $\begin{array}{l}7 \\
3\end{array}$ & $\begin{array}{r}71 \\
10()\end{array}$ & $\begin{array}{l}71 \\
67\end{array}$ & $\stackrel{0}{-}$ & () & $\stackrel{0}{-}$ & 0.3034 \\
\hline \multicolumn{8}{|c|}{$\begin{array}{l}\text { Histology } \\
\text { adenocarcinoma }\end{array}$} \\
\hline $\begin{array}{l}\text { adenocarc } \\
\text { P-gp }+\end{array}$ & 62 & & 77 & 5) & & 51 & \multirow{2}{*}{$0.01+69 *$} \\
\hline$P$-gp- & 30 & 96 & 84 & 79 & 79 & 79 & \\
\hline \multicolumn{8}{|c|}{ squamous cell carcinoma } \\
\hline P-gp- & 26 & 96 & 82 & 73 & 73 & 73 & (0.) $(0+77 * *$ \\
\hline \multicolumn{8}{|c|}{ large cell carcinoma } \\
\hline P-gp+ & 3 & 50) & 50 & 50 & 50 & 5) & \multirow[t]{2}{*}{0.9287} \\
\hline \multirow{2}{*}{\multicolumn{8}{|c|}{$\begin{array}{l}\text { Degree of differentiation } \\
\text { well }\end{array}$}} \\
\hline & & & & & & & \\
\hline P-gp+ & 42 & 9.5 & 85 & 66 & 66 & 57 & \multirow[t]{2}{*}{0.0944} \\
\hline $\begin{array}{l}\text { P-gp- } \\
\text { moderatel }\end{array}$ & 2.5 & 95 & 91 & 86 & 86 & 86 & \\
\hline $\mathrm{P}$-gp+ & 37 & 83 & 68 & +1 & +1 & - & \multirow[t]{2}{*}{0.0713} \\
\hline P-gp- & 26 & 96 & 78 & 71 & 71 & 71 & \\
\hline $\begin{array}{l}\text { poorly } \\
\text { P-gp+ }\end{array}$ & 12 & 63 & 47 & 47 & 47 & 47 & \multirow[t]{2}{*}{0.9458} \\
\hline$P-g p-$ & 6 & 81 & 58 & 46 & 46 & - & \\
\hline \multicolumn{8}{|c|}{$\begin{array}{l}\text { Curability of operation } \\
\text { complete resection }\end{array}$} \\
\hline$P-g p+$ & 77 & 89) & 76 & $60)$ & 50 & 50 & \multirow[t]{2}{*}{$0.00138^{*}-x$} \\
\hline & 48 & 100 & 90 & 87 & 87 & 87 & \\
\hline \multicolumn{8}{|c|}{ incomplete resection } \\
\hline $\begin{array}{l}\text { P-gp+ } \\
\text { P-gp - }\end{array}$ & 15 & 72 & 51 & 34 & 34 & $x^{31}$ & 0.68 .32 \\
\hline Total & & & & & & & \\
\hline${ }^{P-g p+}+$ & 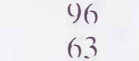 & $\begin{array}{l}84 \\
93 \\
93\end{array}-x-2$ & $\begin{array}{l}73 \\
80\end{array}$ & $\begin{array}{l}54 \\
7+\end{array}$ & $\begin{array}{l}48 \\
74\end{array}$ & $\begin{array}{l}48 \\
74\end{array}$ & (0. $0.3 .57 *$ \\
\hline
\end{tabular}

P-gp +. patients with P-glycoprotein: P-gp--patients withoul P-glycoprotcin

Table 3. Pattient characteristics related to survival according to a multivariate analysis using the Cox rearession model

\begin{tabular}{|c|c|c|c|}
\hline Prognostic factor & Regression coefficient & Chi-squared & $P$ Valu \\
\hline Size of tumor & 0.0228 & 27.947 & \\
\hline Curability of operation & 0.7635 & 16.331 & \\
\hline P-Gilycoprotein & 1.3892 & 6.659 & 0.010 \\
\hline Sex & 1.6806 & 11.823 & 0.001 \\
\hline Nodal status & 0.4158 & 5.49() & \\
\hline
\end{tabular}




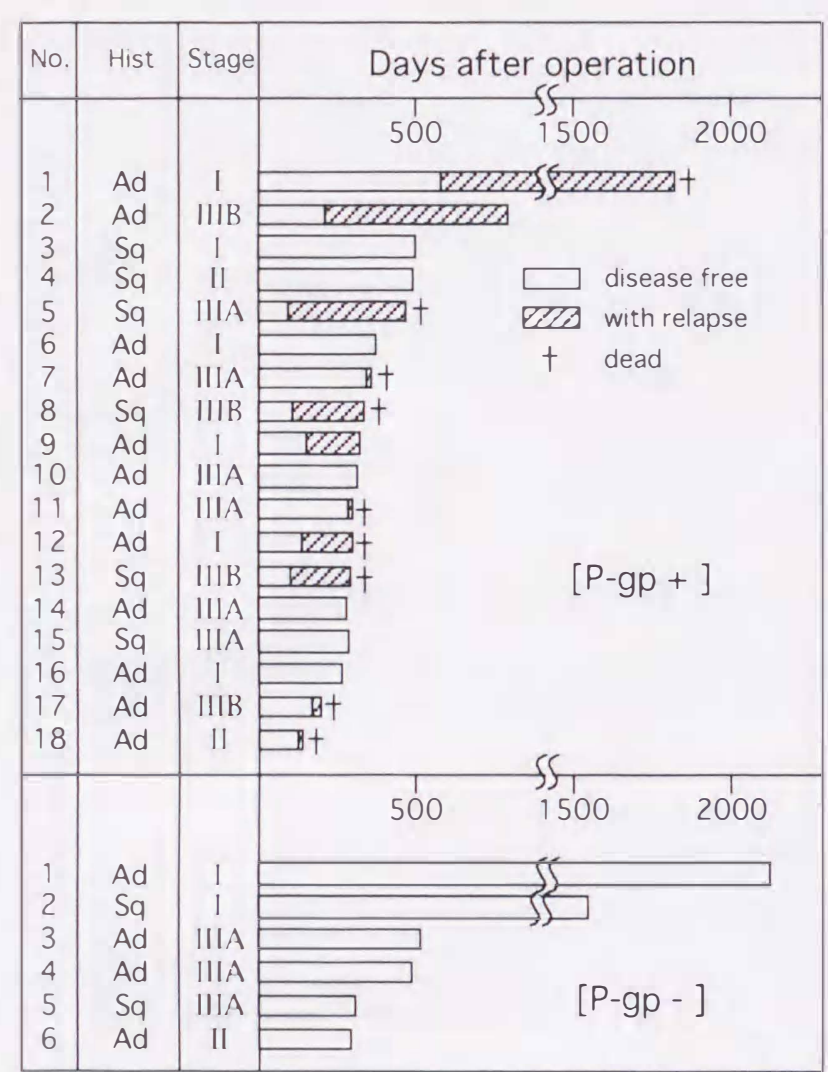
Fig. 3. Clinical courses of patients who underwent complete
resection and postoperative adjuvant chemotherapv. according to immunoreactivity for P-glycoprotein

series was limited, these findings suggest that the prescription of postoperative chemotherapy reflects the prognosis of patients with P-gpt non-small cell lung cancer. Therefore. P-glycoprotein may serve as a chemotherapeutic indicator.

Many researchers have reported that the strongest expression of P-glvcoprotein is found in normal tissues of the kidney. adrenal gland, liver. and intestine." which indicates that the primary role of P-glycoprotein in normal tissue is to secrete physiological metabolites and ingested chemicals into bile. urine. and the lumen of the intestinal tract. P-(ilycoprotein is also expressed in lung. colon. hreast. and ovarian cancers. and in leukemia. ${ }^{24}$

Sugawara reported that the monoclonal antibody (MRK16) for P-glycoprotem revealed immunohistochemical reactivities in all calses of functional hormone-producing adrenal tumors. I case of insulinoma. 2 cases of untreated colonic cancer. I case cach of gastric cancer and breast cancer. 6 cases of renal cell carcinoma, and 17 cases of hladder cancer." $\mathrm{He}$ also reported that the expression was found in one of 10 cases of lung cancer. This incidence of immunoreactivity is much lower than that observed in out present study: however, the different monoclonal antibodies for P-glycoprotein that were used in each study would pre sumably account for the discrepancy.

Mizoguchi et al. reported that well-differentiated colorectal carcinomas contained significantly highe concentrations of $m d r l$ RNA than moderately differentiated colorectal carcinomass ${ }^{24}$ In our study, there was
no significant difference in the immunohistochemical no significant difference in the immunohistochemica expression of P-glycoprotein among well-differentiated. moderately differentiated. and poorly differentiated tumor cells. Howerer. in cases of large eetil carchoma. 1 he incidence of P-gp + was less than that of P-gp-. Large cell carcinoma has many clinicopathological properties that are quite different from those of adenocarcinom or squamous eetl carcinoma. Thus, the poor sensitivity (o) chemotherapeutic agents and the poor prognos associated with large cell carcinoma may be attributable to factors other than P-glycoprotein.

A direct correlation between P-glycoprotein and drug resistance has been studied by many researchers. In studies on breast carcinomas, P-glycoprotein was rarel found in patients not given prior chemotherapy.20.27 in other malignancies, such as ovarian carcinomas ${ }^{\text {and and }}$ pediatric tumors. ${ }^{29.31}$ P-glycoprotem was detected only atter the patients had ingested anticancer drugs. On the other hand. none of our patients had been give

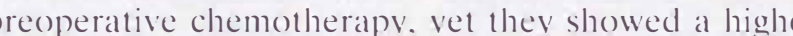
positive rate of immunoreactivity for P-glycoprotei Wishart et al. reported that 26 of 29 patients with reated breast cancer showed a positive immunoreactivity for the monoclonal antibody $\mathrm{C} 219$. ${ }^{31}$ They stated tha significant levels of P-glycoprotem expression may he present in breast cancer hefore exposure to drugs and is associated with multidrug resistance. Our findings support this point of vicw.

There are few reports correlating immunohistochemical results with the clinical outcome of patients. verrelle et al. reported that P-glvcoprotein-positive staining in 17 patients with breast cancers treate with chemotherapy was significantly correlated with no) intial response to chemotherapy and with a shorter progression-free survival. ${ }^{25}$ C hen et al. analyzed the outcome of 67 patients with neuroblastomas and found that the group with negative staining for P-glvecoprotein had significantly longer relapse-free and overall surviva than the group with positive staining. ${ }^{32}$ Although there are many other factors. P-glycoprotein is one of the most promising factors affecting the prognosis of patients with non-small cell lung cancer.

In conclusion. the findings of this study on the $\mathrm{P}$ glycoprotein expression of non-small cell lung cancers have important implications for clinical oncology. Thus we helieve that examining tumors for P-glycoprotein will aid in planning adjuvant therapy for patients with non-small cell lung cancer.
Acknowledgments. We thank Dr. K. Akazawa of the Department of Medical Informatics. Kyushu University Hospital. for
addvice on the statistical analyses, and Dr. B..T. Ouimm of Kvushu University for critical eomments on the mamuscript and useful suggestions.

\section{Refirences}

Ministry of Ilealth and Weltare (1095) Vital statistics of tapaln 1993. vol. 3. Ministry of Health and Weltare, Jappat

Ishida T. Yokoyama H. Kancko S. Sugio K. Sugimachi K (1990) L.ong-term results of operation for non-simall cell lung cancer in he elderly. Ann Thorac Surg 5(t:919-92-2

atcishi M. Sugimachi K'

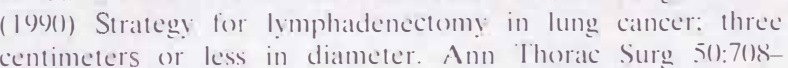
71.3 Tsubota N. Yoshimura M (1906) Skip metastasis and hidden N2 Tsubota N. Yoshimura M (19)(n) Skip metastasis and hidden N2
discease in lung canncer: how successful is mediastinal dissection? discease in lung cancer:
Surg Todiav $26: 16(6)-172$

Mountain C (1986) A new international staging system for lung cancer. ('hest 89(Suppl.):2255-23.35

Henced comparison of then-small cell carcinomia of the lung. The Lung Cancer Study (iroup. Ann Surg 2(12:335-3+1

Shiclds TW. Hoggins GiA. Humphrey EIW. Matthews MII. Kechn R.J. (1982) Prolonged intermittent adjuvant chemotherapy with Cancer 50:1713-1721

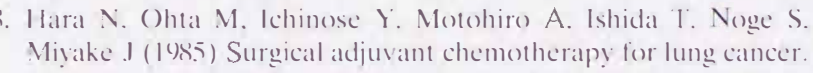
10: Ishigami I (ed) Recent advances in chemotherapy: proceed gins of the 14the International Congress on (hemotherapy 9. Giros P. Neriah Y Y B. (Troop. IM. Housman DE (1986) Isolation and cxpression of a complementary DNA that confers multidrug

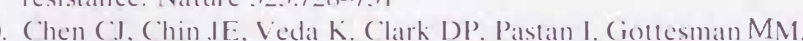

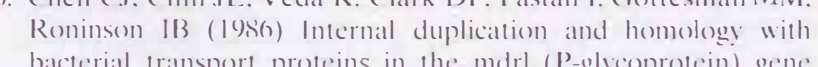
bacterial trantsport proteins in the metrl (P-glycoprotein) gene Irom multidrug-resistant human cells. Cell 47:381-384) glycoprotein-mediated multidrug resistante in normal and neo.ing V (1995) P-glycoprotcin: its role in drug resistance. Am .

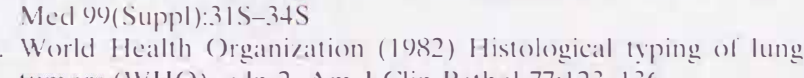
14. Grogan T. Dalteon W. Rviski I. Spier (: Meltzer P. Richter I. Gileason M. Pindur J. Cline A. Scheper R, Tsuruo T. Salmen S (19)(0) Optimization of immuntectochemical P-gly coprontein as vessment in multidrug-resistant plasma cell myeloma using three inge methods based on the avidin-biotin imeraction Dien Dixon W.J (ed) (1)SSS) BMDP statistical soltware. University of Calitionnia Press. Berkeley. 13.34. pp 187-221

haptan FI. Mecer P (195) Non-parametric estimation tron Petp R. Pike MC. Armitage P. Brestlow NE. COX DR. How and SV. Mantel N. MePherson K. Peto J. Smith P'G (1977) Design and

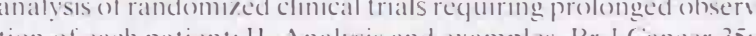

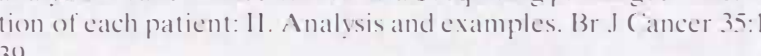
Cox DR (1972) Regression models and life tables. I R Stat Soc B $3+: 187-2201$

Gollesmatn MM, Pastan I. Ambudkar SV (19)6) P-glvecoprotein and multidrug resistiance. ( Cirr Opin Genet Deve 6:6181)-617

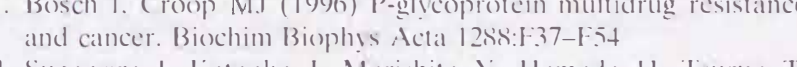

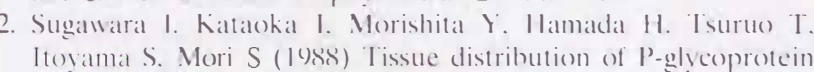
Itovamas. Sori S (1988) Tissue distribution of P-glycoprotein
encoded by a multidrug-resistant gene as revealed hy a monoclonal antibody. MRK I6. Cancer

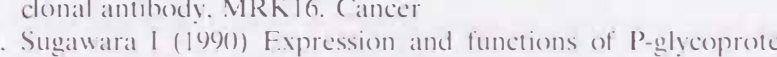
(midrl gene product) in normal and malignant tissues. Acta Pather

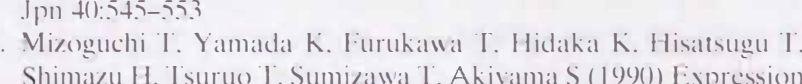
of the MIDR! gene in human gastric and colorectal carcinomas I Nall Cancer Inst 82:1679)-16.83.3

Verrelle P. Meissonnier F. Fonck Y. Feillel V. Dioner Kwaitkonski F. Plagne R. (Chassagne. I (1991) (linical relevance

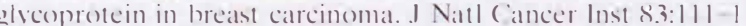
6. Scotto KW. Bielder Jl. Melera PW (1980) Amplification and

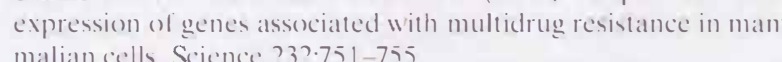

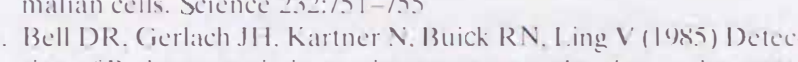

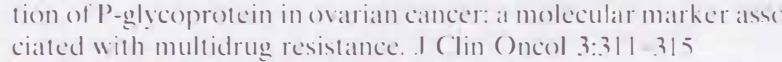
28. Rulledge M. Rober-Cafferty S. Silva E. Bruner I ( I USS) Moneclonal antibody (C219) detection of the multidrug resistamt pre-

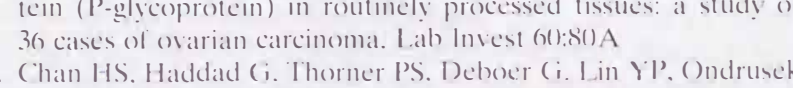

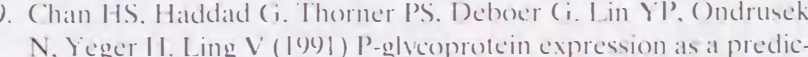
N. Yeger II. Ling V (1901) P-glycoppotcin expression as a predic-
tor of the outcome of therapy for neurohlastoma. N Engl I Med

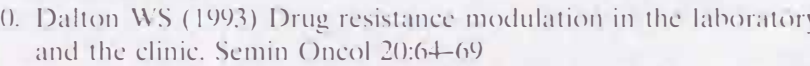
Wishart (iC. Plumb IA. Going III. MeNicol AM. MeArdle CS Tsuruo T. Kave SB (1990) P-glycoprotein expression in primat

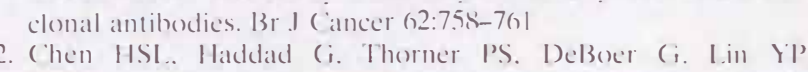

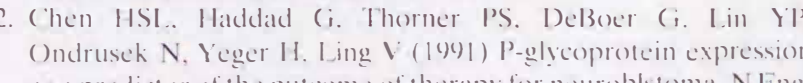
as a predictor of the o
I Med $325: 16(1)-1014$ 


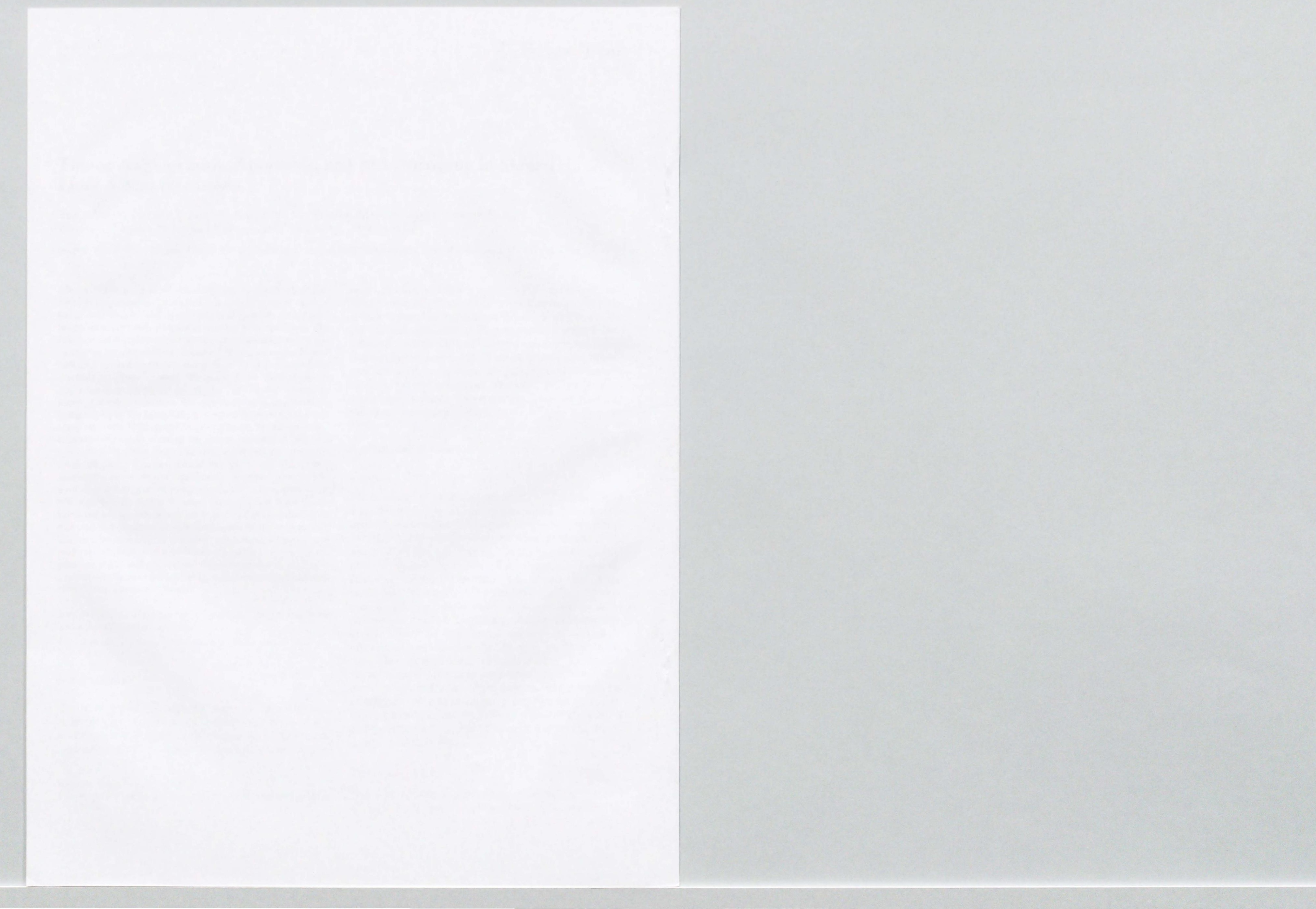

